\title{
SHRUB INVASION OF GRASSLAND: RECRUITMENT IS CONTINUOUS AND NOT REGULATED BY HERBACEOUS BIOMASS OR DENSITY
}

\author{
Joel R. Brown ${ }^{1}$ AND Steve Archer \\ Department of Rangeland Ecology and Management, Texas A\&M University, \\ College Station, Texas 77843-2126 USA
}

\begin{abstract}
Proliferation of woody plants in grasslands and savannas since the $1800 \mathrm{~s}$ has been widely documented. In the southwestern United States, increased abundance of honey mesquite (Prosopis glandulosa var. glandulosa) has been attributed to heavy grazing by livestock. Here, we test the hypothesis that $P$. glandulosa invasion of grasslands requires, first, reductions in herbaceous biomass and density such as those that accompany livestock grazing and, second, episodes of high soil moisture availability.

No combination of grass density (nonmanipulated or reduced 50\%) or defoliation (none, moderate, heavy) significantly affected $P$. glandulosa seedling emergence within a watering regime (natural and supplemented) at our field site in semiarid southern Texas. Seedling emergence on plots receiving only natural rainfall was high $(42 \%)$, despite the fact that precipitation was substantially below normal. Supplemental watering, to generate moisture levels approximating years of unusually high annual rainfall, increased emergence to $59 \%$. Seedling survival after $2 \mathrm{yr}$ was high $(62-77 \%)$ and statistically comparable across the density, defoliation, and watering treatments. Net photosynthesis $\left(A_{\mathrm{n}}\right)$ of 1 -yr-old seedlings was enhanced by supplemental watering, but reductions in grass density or biomass had little effect on seedling $A_{\mathrm{n}}$ or xylem water potential. Height, aboveground biomass, and leaf area were comparable among 1 - and 2-yr-old seedings across all density, defoliation, and watering combinations.

High seedling emergence and survival on unwatered plots, even during a "drought year," suggests that Prosopis recruitment is not contingent upon unusual or episodic rainfall. Reductions in biomass and density of herbaceous vegetation had no influence on seedling emergence, growth, or survival, suggesting that Prosopis invasion is minimally influenced by grass competition. Historic grazing at this site appears to have altered herbaceous composition and reduced above- and belowground biomass production below the threshold level required for competitive exclusion of woody vegetation. Such data suggest that rates and patterns of seed dispersal may be the primary determinants of $P$. glandulosa encroachment on present-day landscapes in semiarid regions. Minimizing livestock dispersal of seed (in the case of leguminous shrubs) and maintenance of an effective fire regime (through production of fine fuels) may be crucial for sustaining herbaceous composition and production in grazed systems prone to invasion by unpalatable woody plants.
\end{abstract}

Key words: Chloris cucullata; competition of invasive woody plants in grasslands; grazing; photosynthesis; Prosopis glandulosa; savanna; seedling establishment; tree-grass interactions; woody plant invasion; xylem water potential.

\section{INTRODUCTION}

Trends toward increasing woody plant abundance in temperate and tropical grasslands and savannas in recent history have been reported worldwide (Archer 1994, McPherson 1997). Although this phenomenon has been widely recognized (e.g., Grover and Musick 1990) and has significant implications for livestock production systems (Scifres 1980, Scifres et al. 1983), wildlife habitat (Ben-Sharer 1992), and biogeochemistry (Schlesinger et al. 1990), surprisingly little is known of the rates, dynamics, patterns, or successional

Manuscript received 12 March 1998; revised 28 September 1998; accepted 30 September 1998.

${ }^{1}$ Present address: USDA/NRCS, Jornada Experimental Range, P.O. Box 30003, MSC 3JER, New Mexico State University, Las Cruces, New Mexico 88003-0003 USA processes involved in these vegetation changes. Climatic change and changes in historical atmospheric $\mathrm{CO}_{2}$ concentrations, fire regimes, rodent populations, and livestock grazing have been suggested as driving forces in this shift in vegetation (Archer et al. 1995, Polley et al. 1996, Brown et al. 1997, Weltzin et al. 1997). While all of these factors have interacted to produce vegetation change, some studies (e.g., Madany and West 1983) have clearly demonstrated that livestock grazing has been a primary factor.

For woody plants with potentially long life-spans and low post-establishment mortality rates, seedling recruitment is probably the most critical stage in the life history (Harper 1977). A variety of direct and indirect effects of livestock grazing may interact to promote woody plant seedling establishment in grass commu- 
nities (Archer 1995a). Reductions in the density and biomass of herbaceous vegetation have been shown to increase the probability of seedling success in old fields and forests (i.e., Goldberg and Werner 1983, Maguire and Forman 1983, McEvoy 1984, De Steven 1991a, $b)$. Changes in species composition and reductions in herbaceous plant basal area, density, and above- and belowground biomass known to accompany chronic livestock grazing (Heitschmidt and Stuth 1991) might therefore create opportunities for tree and shrub seedling establishment in grasslands. Although it is widely assumed that these grazing-induced changes in community structure and function will increase grassland susceptibility to woody plant encroachment, these potential controlling factors have not been adequately quantified.

Experimental studies of woody plant invasion of semiarid grasslands that focus on the critical seedling establishment phase are relatively few and have been primarily controlled environment studies. Such studies predict that reductions in grass competition (achieved via reductions in biomass associated with defoliation) will promote woody plant seedling establishment (van Auken and Bush 1987, 1988, 1989, Polley et al. 1994). Some field studies support this contention (Schultz et al. 1955, McPherson 1993, Bush and van Auken 1995), but others do not (Brown and Archer 1989, Schmidt and Stubbendieck 1993, O'Connor 1995a). Here, we investigated the extent to which changes in herbaceous density and biomass influence woody plant seedling establishment in grasslands under field conditions.

Climatic variability and the unpredictable occurrence of extreme climatic events may interact with grazing to effect rapid shifts in plant recruitment and mortality and change the balance between grasses and woody plants (e.g., Wiegand et al. 1995). Periods of elevated rainfall may trigger episodes of seed production and seedling establishment of woody plants in grasslands (McPherson and Wright 1990, Turner 1990, Harrington 1991, Carter 1994), while drought may promote grass die-off (O'Connor 1993), but have little effect on tree or shrub persistence (Carter 1964, Neilson and Wullstein 1985). It is not clear how rainfall variability might constrain, accentuate, or mitigate grazing influences on woody plant emergence and establishment in grasslands.

In southwestern North America, many temperate, subtropical, and desert grasslands and savannas present at the time of Anglo-European settlement are now shrublands or woodlands dominated by the tree legume, honey mesquite (Prosopis glandulosa var. glandulosa Torr.) (Archer 1989, 1994). The encroachment of $P$. glandulosa into grasslands and savannas has had significant socioeconomic and environmental impacts on these lands that have been predominantly used for livestock grazing (Fisher 1950, Simpson 1977). An understanding of processes regulating $P$. glandulosa seedling recruitment is, therefore, a critical first step in developing management strategies to mitigate shrub encroachment. In this study we examined simulated grazing $\times$ soil moisture $\times$ grass competition interactions on $P$. glandulosa seedling emergence and shortterm survival. We hypothesized that under conditions of high soil moisture, competition with grasses would be minimal and $P$. glandulosa would successfully germinate and establish regardless of herbaceous biomass and density. This would be the anticipated scenario if seedling establishment were "episodic" and confined to years when rainfall is unusually high. We hypothesized that, conversely, under conditions of low soil moisture ("normal" or below normal rainfall) competition with grasses would be intense and $P$. glandulosa germination and establishment would occur only with a reduction in grass biomass or density, such as that which typically accompanies chronic livestock grazing. To test these hypotheses, we conducted a factorial field experiment, whereby seeds of $P$. glandulosa were planted into plots maintained at two graminoid densities (nonmanipulated and reduced 50\%), receiving one of three levels of defoliation (none, moderate, and heavy) and one of two watering regimes (natural and supplemented).

\section{Materials And Methods}

\section{Study site}

Research was conducted on the Texas Agricultural Experiment Station, La Copita Research Area, in Jim Wells County, $15 \mathrm{~km} \mathrm{SW}$ of Alice, Texas $\left(27^{\circ} 40^{\prime} \mathrm{N}\right.$, $98^{\circ} 12^{\prime} \mathrm{W}$; elevation $80 \mathrm{~m}$ ) in the eastern Rio Grande Plains of the Tamaulipan Biotic Province. Contemporary vegetation of the region has been described by Davis and Spicer (1965). Uplands at the study site, which have been grazed by cattle since the late 1800 s, are savanna parklands consisting of discrete clusters of woody plants organized beneath Prosopis glandulosa (plant nomenclature follows Correll and Johnston 1979). Inter-cluster spaces were dominated by perennial grasses, primarily Chloris cucullata. See Archer (1995b) for details on plant community structure and successional patterns. Soils on the study site were fine sandy loams (Runge series) on 1-3\% slopes (USDA 1979). Climate is subtropical, with warm winters and hot summers. Mean annual temperature is $22.4^{\circ} \mathrm{C}$, with a growing season of $289 \mathrm{~d}$. Mean annual precipitation $(720 \mathrm{~mm})$ is highly variable $(\mathrm{CV}=35 \%)$. When tropical depressions and hurricanes in the Gulf of Mexico spawn inland storms, annual rainfall may exceed 2600 mm. Available weather records for Alice, Texas, indicate there have been five such years between 1912 and 1997 (1919 [3312 mm], 1935, 1941, 1942, and 1971).

\section{Field experiments}

In May 1984 livestock were excluded from a $60 \times$ $60 \mathrm{~m}$ area. Seventy-two $2 \times 1 \mathrm{~m}$ plots were perma- 
nently marked within this exclosure. One-half of the plots (hereafter referred to as "watered" plots) received supplemental water applied every other week ( $\sim 10 \mathrm{~cm}$ each application) from April through October 1984 and 1985 via low pressure irrigation. Our goal was to elevate moisture to levels approximating the highest annual rainfall years in the weather records for this area (2600-3312 mm). The other half of the plots (hereafter referred to as "unwatered") received only natural rainfall. Approximately $10 \mathrm{~m}$ separated the watered and unwatered plots. Watered plots were located downslope from unwatered plots to eliminate the possibility of run-on. Herbaceous density and defoliation treatments were randomly assigned to plots within watering treatments.

Density was altered in half of the plots in each watering treatment by placing a gridded $2 \times 1 \mathrm{~m}$ frame over each plot and killing $50 \%$ of the plants in each $0.25-\mathrm{m}^{2}$ block with a nonselective, foliar-active herbicide (glyphosate [N-(phoshonomethyl) glycine]). Plant density was estimated $30 \mathrm{~d}$ later using the gridded plot frame to map individual plants, and herbicide was reapplied as necessary. Post-treatment bare ground cover percentages averaged $51 \pm 6 \%$ in the control plots vs. $75 \pm 7 \%$ in the reduced density plots. The relative composition of species in density-altered plots remained similar to that of the normal-density plots.

Three levels of defoliation (none, moderate $[20 \mathrm{~cm}$ stubble height], and heavy [ $5 \mathrm{~cm}$ stubble height]) were imposed by clipping monthly throughout the experiment. All clipped biomass was removed from plots. Thus, we imposed a 12-treatment factorial design (three levels of defoliation, two levels of herbaceous density, two levels of watering). Each of the 12 treatments was replicated six times (total $=72$ plots).

\section{P. glandulosa emergence, establishment and growth}

Prior to the initiation of the experiment, no P. glandulosa plants were inside the exclosure. In early July 1984, 30 seeds were planted at a depth of $2 \mathrm{~cm}$ in each $2 \times 1 \mathrm{~m}$ plot. Laboratory viability trials conducted at $25^{\circ} \mathrm{C}$ on a random subsample $(N=1000$ seeds $)$ of the seed lot indicated that $96 \%$ were germinable. Seedling emergence was determined 2 wk after planting. Seedling survivorship was noted in October 1984 and again in April and August of 1985. A second cohort of seeds (laboratory germinability $=95 \%$ ) was planted in late June 1985, and their growth and survival monitored for the remainder of that field season. These planting dates roughly coincide with periods of $P$. glandulosa seed production at this field site.

Seedling performance was estimated for seedlings in four of the 12 treatment combinations: unwatered-normal density-no defoliation (UNN = control), unwatered-low density-heavy defoliation (ULH), waterednormal density-no defoliation (WNN), and wateredlow density-heavy defoliation (WLH). For each of these treatments, net photosynthesis $\left(A_{\mathrm{n}}\right)$ and xylem water potential $(\Psi)$ of seedlings were quantified on six dates during 1985. Diurnal measurements of gas exchange (at 0900, 1200, and 1600) on clear days in May, June, July, and August were made on upper/lower leaf surfaces with a portable photosynthesis system (LI6000, LI-COR, Inc., Lincoln, Nebraska, USA) and a 0.25 -L cuvette. At least three $P$. glandulosa seedlings per treatment were followed through each day.

Xylem water potential was determined with a pressure chamber (Scholander et al. 1965). Seedlings were placed in plastic bags containing moistened filter paper after excising to minimize water loss during pressure chamber readings. Seedling $\Psi$ was not checked during June 1985 to ensure that an adequate number of seedlings would be available for measurements during the more stressful period of the growing season. Individual $P$. glandulosa seedlings destructively harvested for $\Psi$ measurements were used to determine aboveground biomass, height, and leaf area.

Soil water content in plots (15 and $30 \mathrm{~cm}$ and at 30 $\mathrm{cm}$ increments to $1.5 \mathrm{~m}$ depth) was estimated (neutron scattering method, van Bavel 1958) in each of the four treatments where plant performance measurements were made (UNN, ULH, WNN, and WLH). Neutron access tubes were read monthly. Soil temperature was estimated on the same plots at 5 and $20 \mathrm{~cm}$ depths, using thermocouples $(N=4)$. Aboveground herbaceous biomass was estimated by clipping $0.25-\mathrm{m}^{2}$ plots $(N=10)$ in June 1984 and June 1985 at peak standing crop.

Analysis of variance (ANOVA) of arcsine transformed data (Snedecor and Cochran 1980) was used to test for differences in seedling emergence and survival among the 12 treatments. We used a split-plot ANOVA model with water (two levels) as the main treatment, and grass density (two levels) and grass defoliation (three levels) as subplot treatments. Statistical differences in $A_{\mathrm{n}}(P \leq 0.05)$ among the four treatments (UNN, ULH, WNN, WLH) were tested with repeated measures analysis of variance (Keppel 1982). Differences in mean $\Psi$, standing crop biomass, and soil moisture (by depth) among these treatments were tested with standard ANOVA.

\section{RESULTS}

Aboveground herbaceous biomass was comparable for all plots when the experiment was initiated in June 1984 (Table 1). Supplemental watering subsequently increased aboveground herbaceous biomass relative to nonsupplemented (unwatered) control plots. However, density reduction and clipping combinations offset watering effects, such that there were no differences on any date between WLH plots and UNN plots. Standing crop biomass on the ULH plots was significantly less than all other treatments. Standing crop on WNN plots was significantly greater than all others during 1985 . $P$. glandulosa seedlings were thus exposed to herba- 
TABLE 1. Standing crop biomass $\left(\mathrm{g} / \mathrm{m}^{2}\right)$ on watering, herbaceous density, and clipping treatments in summer 1984 at the start of the experiment and in 1985

\begin{tabular}{llc}
\hline \hline & \multicolumn{2}{c}{ Standing crop biomass $\left(\mathrm{g} / \mathrm{m}^{2}\right)$} \\
\cline { 2 - 3 } Treatment & 1984 & 1985 \\
\hline ULH & $262^{\mathrm{a}}(18)$ & $185^{\mathrm{a}}(13)$ \\
UNN & $278^{\mathrm{a}}(20)$ & $292^{\mathrm{b}}(21)$ \\
WLH & $255^{\mathrm{a}}(21)$ & $263^{\mathrm{b}}(19)$ \\
WNN & $245^{\mathrm{a}}(21)$ & $453^{\mathrm{c}}(25)$ \\
\hline
\end{tabular}

Notes: Values are means of six, $2 \times 1 \mathrm{~m}$ plots $(1 \mathrm{SE}$ in parentheses). Treatments are: unwatered, low density, heavy defoliation (ULH); unwatered, normal density, no defoliation (UNN); watered, low density, heavy defoliation (WLH); and watered, normal density, no defoliation (WNN). $N=10$ plots per treatment. Means within a column followed by different letters were statistically different $(P<0.05)$.

ceous aboveground biomass ranging from 185 to 453 $\mathrm{g} / \mathrm{m}^{2}$.

Annual rainfall for $1984(506 \mathrm{~mm})$ was well below the long-term average $(720 \mathrm{~mm})$; rainfall in 1985 (760 $\mathrm{mm})$ was slightly above normal. Rainfall during the months preceding the $1984 P$. glandulosa planting was well below normal (35\% of long-term mean for January-June), whereas monthly rainfall for the months preceding the 1985 planting was well above normal (Fig. 1).

Supplemental watering increased soil moisture content relative to unwatered controls, and date $\times$ water treatment interactions were significant $(P \leq 0.05$, Fig. 2 ). Neither plant density nor level of defoliation significantly influenced soil moisture, so data in Fig. 2 were pooled across these treatments. At the time of planting (July 1984), soil water content at $15 \mathrm{~cm}$ was significantly greater in the watered plots $(37 \%)$ than in the unwatered plots $(20 \%)$.

Analysis of variance indicated no significant differences in soil temperatures within a watering treatment. Soil temperature data were therefore pooled across defoliation-density treatments. Soil temperature date $\times$ watering treatment interactions were significant at each depth $(P<0.05)$. Soil temperature at $5 \mathrm{~cm}$ was significantly $(P<0.05)$ reduced on watered plots in 1984 and after 2 July, 1985 (Fig. 3). At the time of planting, soil temperatures at $5 \mathrm{~cm}$ were significantly $(P<0.05)$ greater on unwatered plots compared to watered plots. Temperatures at $20 \mathrm{~cm}$ followed a similar pattern, although the magnitude of the differences was less. Peak soil temperatures in the upper $5 \mathrm{~cm}$ typically exceeded $35-40^{\circ} \mathrm{C}$ each year during the period of $P$. glandulosa seed germination.

\section{Prosopis seedling emergence and establishment}

$P$. glandulosa seedling emergence in unwatered plots (42\% and 44\% in 1984 and 1985, respectively) was significantly $(P<0.01)$ less than that which occurred in plots receiving supplemental water $(59 \%$ and $62 \%$, Table 2). However, watering did not significantly enhance first-year survival of seedlings emerging in 1984 $(P=0.06)$ or $1985(P=0.09)$ nor second year survivorship of the 1984 cohort $(P=0.08)$. Density and level of defoliation of herbaceous vegetation affected neither emergence ( $P=0.15$ and 0.24 , respectively)

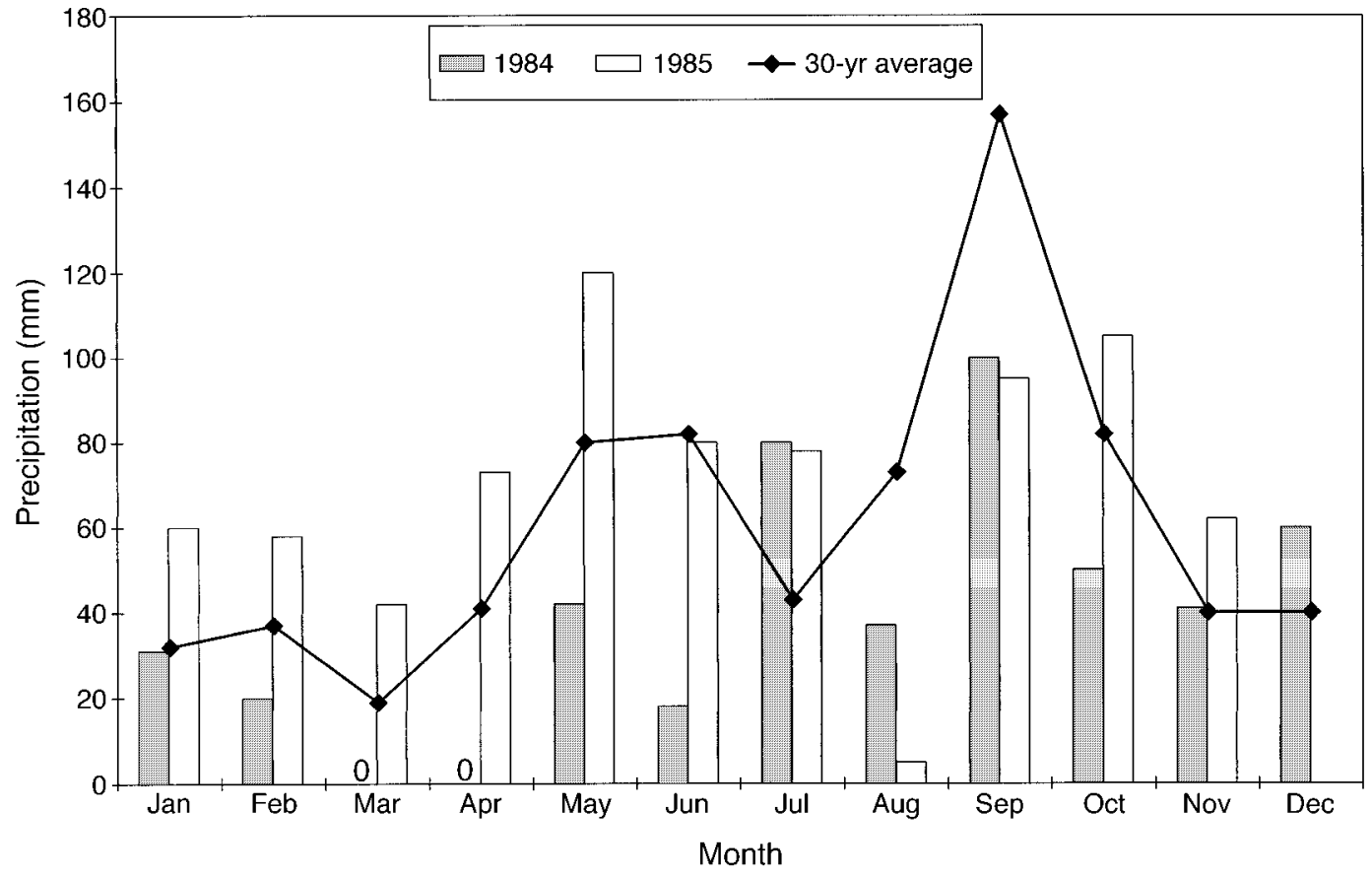

FIG. 1. Monthly precipitation (mm) at Alice, Texas, for 1984 (shaded bars), 1985 (open bars), and the 30-yr average (solid line). 

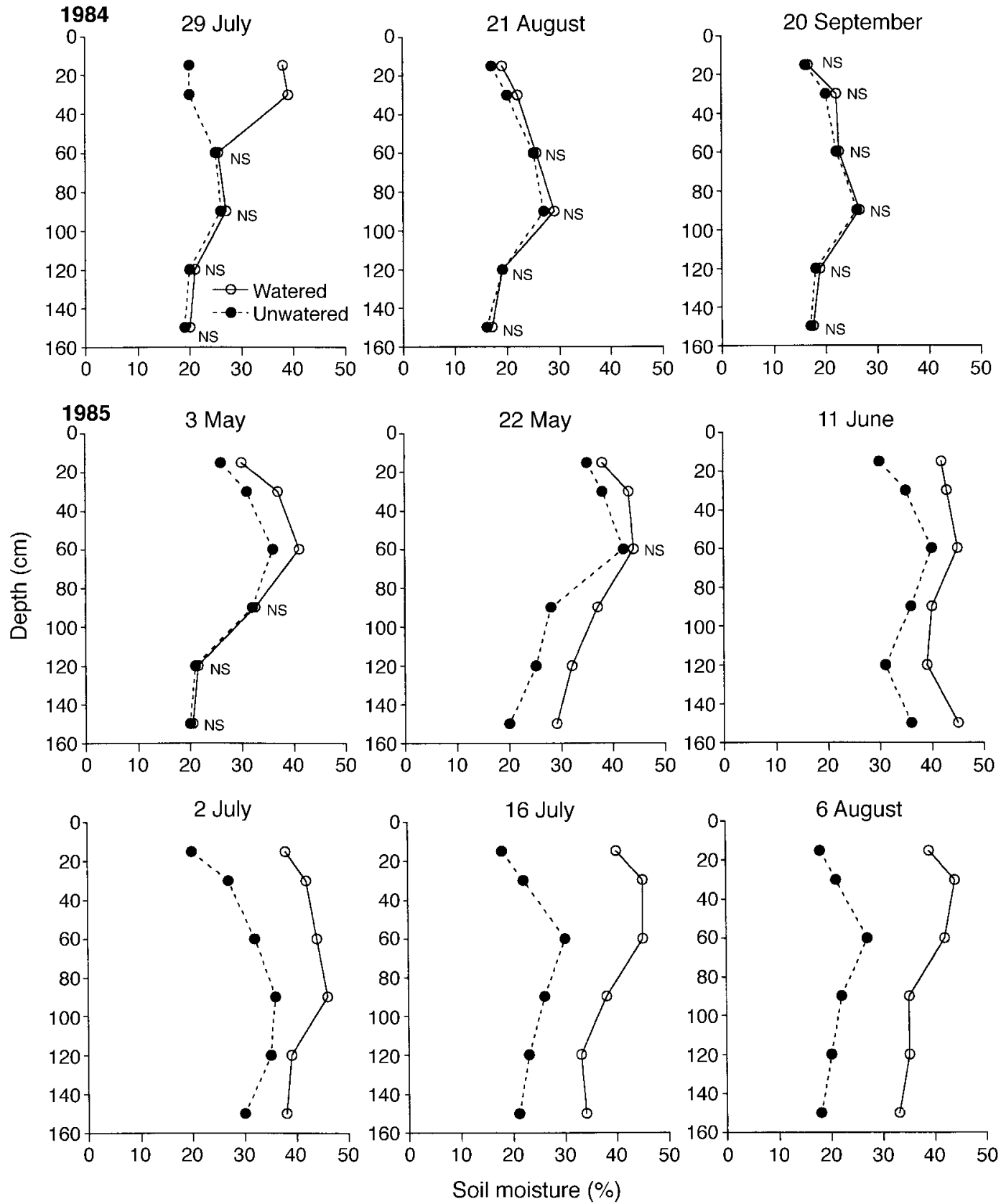

FIG. 2. Soil moisture (percentage) in 1984 and 1985 on plots receiving only natural rainfall ("unwatered") and on plots receiving supplemental watering ("watered"). For a given depth/date, soil moisture differences between watered and unwatered plots were significant $(P \leq 0.05)$, except where noted as NS.

nor survival $(P=0.28$ and 0.11 , respectively, for firstyear survival; $P=0.65$ and 0.71 , respectively, for second-year survival) of seedlings within a watering regime, even though differences in aboveground biomass among those treatments were significant (Table 1). Interaction terms were nonsignificant, with one exception: water $\times$ density for second-year seedling survival. In this instance, herbaceous density reductions had a slight negative effect on second-year survival among watered seedlings (85 vs. $82 \%$ ), whereas among unwatered seedlings, experimental reductions in grass density had a slight positive effect ( 75 vs. $82 \%$, Table 2).

Seasonal and diurnal patterns of net photosynthesis $\left(A_{\mathrm{n}}\right)$ and xylem water potential $(\Psi)$ of 1-yr-old seedlings generally reflected seasonal variation in soil moisture (Tables 3 and 4). There were no statistical differences across watering treatments during May, when soil 


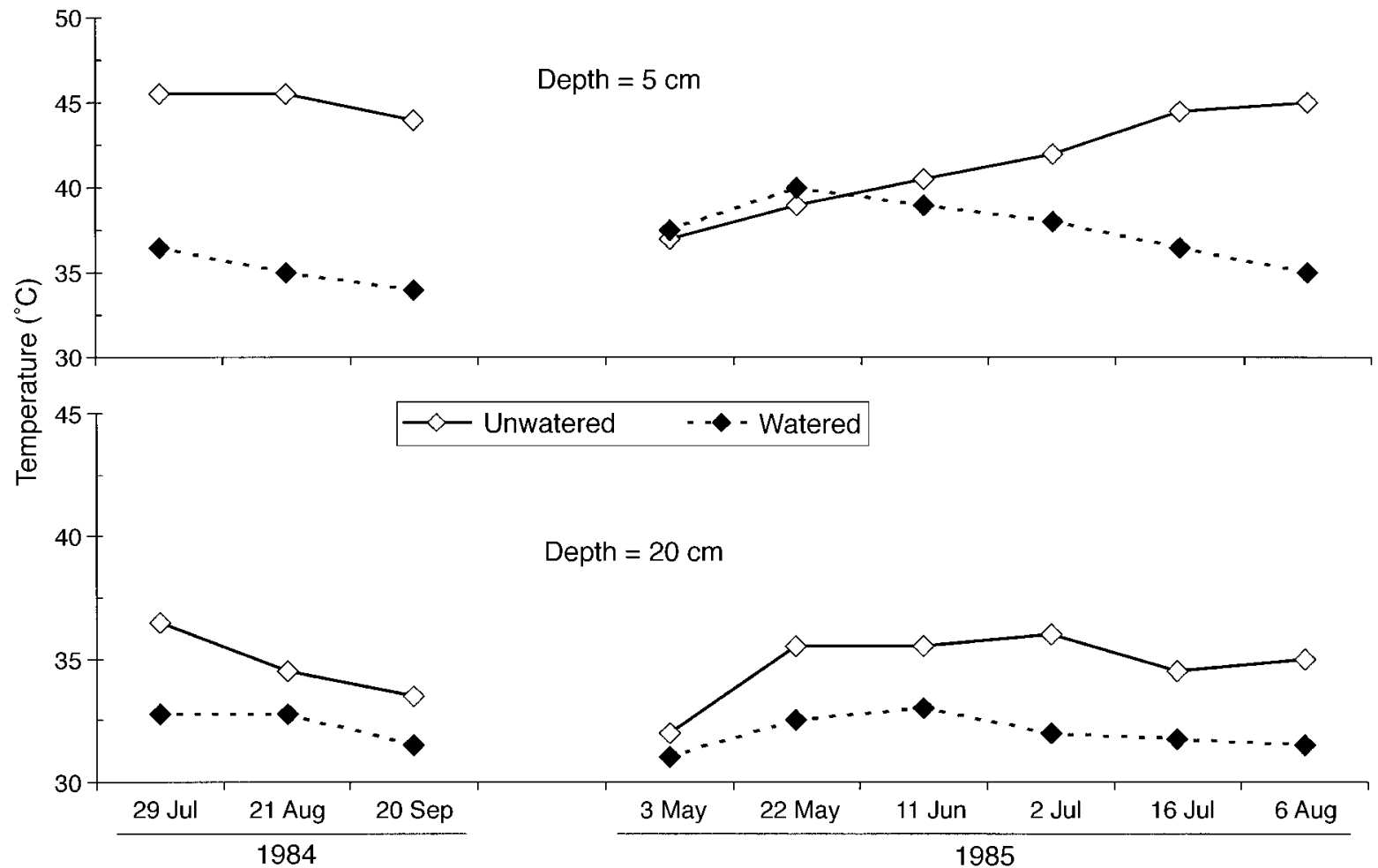

FIG. 3. Mean soil temperature $\left({ }^{\circ} \mathrm{C}, N=4\right)$ at 5 - and 20 -cm depths on plots receiving only natural rainfall ("unwatered") and on plots receiving supplemental watering ("watered").

TABle 2. Emergence (percentage) of two P. glandulosa seedling cohorts (1984 and 1985) and survival (percentage) of the 1984 cohort through 1985 in plots manipulated with respect to soil moisture and the density and level of defoliation of herbaceous plants.

\begin{tabular}{|c|c|c|c|c|c|}
\hline \multirow[b]{3}{*}{ Treatment } & & & \multicolumn{3}{|c|}{ Survival (\%) } \\
\hline & \multicolumn{2}{|c|}{ Emergence $(\%)$} & \multicolumn{2}{|c|}{1 st year } & \multirow{2}{*}{$\begin{array}{c}\text { 2nd year } \\
1984 \text { cohor }\end{array}$} \\
\hline & 1984 cohort & 1985 cohort & 1984 cohort & 1985 cohort & \\
\hline Watered $\dagger$ & 59 & 62 & 80 & 72 & 84 \\
\hline $\begin{array}{l}\text { Normal density } \dagger \\
\text { No defoliation } \\
\text { Moderate defoliation } \\
\text { Heavy defoliation }\end{array}$ & $\begin{array}{l}59 \\
58^{\mathrm{a}} \\
56^{\mathrm{a}} \\
62^{\mathrm{a}}\end{array}$ & $\begin{array}{l}63 \\
60^{\mathrm{a}} \\
65^{\mathrm{a}} \\
63^{\mathrm{a}}\end{array}$ & $\begin{array}{l}82 \\
82 \\
80 \\
85\end{array}$ & $\begin{array}{l}74 \\
75 \\
70 \\
77\end{array}$ & $\begin{array}{l}85 \\
86 \\
88 \\
82\end{array}$ \\
\hline $\begin{array}{l}\text { Reduced density } \dagger \\
\text { No defoliation } \\
\text { Moderate defoliation } \\
\text { Heavy defoliation }\end{array}$ & $\begin{array}{l}60 \\
58^{\mathrm{a}} \\
62^{\mathrm{a}} \\
59^{\mathrm{a}}\end{array}$ & $\begin{array}{l}62 \\
62^{\mathrm{a}} \\
60^{\mathrm{a}} \\
63^{\mathrm{a}}\end{array}$ & $\begin{array}{l}77 \\
78 \\
73 \\
79\end{array}$ & $\begin{array}{l}69 \\
70 \\
62 \\
76\end{array}$ & $\begin{array}{l}82 \\
88 \\
80 \\
78\end{array}$ \\
\hline Unwatered $\dagger$ & 42 & 44 & 76 & 66 & 78 \\
\hline $\begin{array}{l}\text { Normal density } \dagger \\
\text { No defoliation } \\
\text { Moderate defoliation } \\
\text { Heavy defoliation }\end{array}$ & $\begin{array}{l}42 \\
43^{\mathrm{b}} \\
39^{\mathrm{b}} \\
45^{\mathrm{b}}\end{array}$ & $\begin{array}{l}46 \\
46^{\mathrm{b}} \\
43^{\mathrm{b}} \\
48^{\mathrm{b}}\end{array}$ & $\begin{array}{l}74 \\
72 \\
70 \\
80\end{array}$ & $\begin{array}{l}67 \\
63 \\
63 \\
75\end{array}$ & $\begin{array}{l}75 \\
78 \\
75 \\
75\end{array}$ \\
\hline $\begin{array}{l}\text { Reduced density } \dagger \\
\text { No defoliation } \\
\text { Moderate defoliation } \\
\text { Heavy defoliation }\end{array}$ & $\begin{array}{l}41 \\
42^{\mathrm{b}} \\
42^{\mathrm{b}} \\
38^{\mathrm{b}}\end{array}$ & $\begin{array}{l}43 \\
44^{\mathrm{b}} \\
42^{\mathrm{b}} \\
43^{\mathrm{b}}\end{array}$ & $\begin{array}{l}77 \\
75 \\
78 \\
78\end{array}$ & $\begin{array}{l}65 \\
67 \\
66 \\
62\end{array}$ & $\begin{array}{l}82 \\
80 \\
78 \\
88\end{array}$ \\
\hline Significance & $P<0.01$ & $P<0.01$ & $P<0.06$ & $P<0.09$ & $P<0.08$ \\
\hline
\end{tabular}

Notes: For percentage emergence, means within a column followed by different letters were statistically different $(P<$ 0.05). There were no significant differences among means within columns for percentage survival. Significance levels for within-cohort full-model ANOVAs are shown at the bottom of each column.

$\dagger$ Pooled means. 
TAble 3. Net photosynthesis (as moles of quanta, $\mu \mathrm{mol} \cdot \mathrm{m}^{-2} \cdot \mathrm{s}^{-1}$ ) of $P$. glandulosa seedlings on six dates in 1985 . Seedlings were growing on plots that varied with respect to watering regime, herbaceous plant density, and level of herbaceous defoliation (abbreviations as in Table 1).

\begin{tabular}{|c|c|c|c|c|c|c|}
\hline \multirow{2}{*}{$\begin{array}{l}\text { Time of day } \\
\text { and treatment }\end{array}$} & \multicolumn{6}{|c|}{ Date (1985) } \\
\hline & 3 May & 22 May & 11 June & 2 July & 16 July & 6 August \\
\hline \multicolumn{7}{|l|}{0900} \\
\hline ULH & $3.7^{\mathrm{a}}(0.8)$ & $9.5^{\mathrm{a}}(1.5)$ & $6.2^{\mathrm{a}}(1.3)$ & $3.2^{\mathrm{a}}(0.5)$ & $3.2^{\mathrm{a}}(0.9)$ & $3.5(0.6)$ \\
\hline UNN & $8.0^{\mathrm{b}}(1.2)$ & $7.2^{\mathrm{b}}(0.9)$ & $6.1^{\mathrm{a}}(1.0)$ & $4.3^{\mathrm{a}}(0.9)$ & $3.5^{\mathrm{a}}(0.8)$ & $3.7(1.1)$ \\
\hline WLH & $5.0^{\mathrm{ab}}(0.7)$ & $6.5^{\mathrm{b}}(0.5)$ & $14.2^{\mathrm{b}}(2.5)$ & $11.7^{\mathrm{b}}(2.3)$ & $7.5^{\mathrm{b}}(1.5)$ & $3.6(0.9)$ \\
\hline WNN & $5.5^{\mathrm{ab}}(0.9)$ & $6.8^{\mathrm{b}}(0.6)$ & $12.1^{\mathrm{b}}(2.7)$ & $10.2^{\mathrm{b}}(2.6)$ & $8.2^{\mathrm{b}}(2.7)$ & $4.8(1.2)$ \\
\hline \multicolumn{7}{|l|}{1200} \\
\hline ULH & $3.5^{\mathrm{a}}(0.4)$ & $8.1^{\mathrm{a}}(1.8)$ & $5.5^{\mathrm{a}}(1.1)$ & $3.3^{\mathrm{a}}(1.1)$ & $3.5^{\mathrm{a}}(1.1)$ & $1.8(0.7)$ \\
\hline UNN & $4.5^{\mathrm{a}}(0.6)$ & $7.9^{\mathrm{a}}(1.3)$ & $3.3^{\mathrm{b}}(0.6)$ & $4.5^{\mathrm{a}}(1.6)$ & $4.5^{\mathrm{a}}(1.8)$ & $1.7(0.4)$ \\
\hline WLH & $7.0^{\mathrm{b}}(1.2)$ & $7.4^{\mathrm{a}}(1.5)$ & $11.7^{\mathrm{c}}(2.6)$ & $9.9^{\mathrm{b}}(2.3)$ & $8.1^{\mathrm{b}}(2.1)$ & $1.8(0.5)$ \\
\hline WNN & $6.5^{\mathrm{b}}(1.3)$ & $6.1^{\mathrm{a}}(1.4)$ & $10.2^{\mathrm{c}}(2.2)$ & $12.3^{\mathrm{b}}(3.4)$ & $9.8^{\mathrm{b}}(2.8)$ & $0.3(0.2)$ \\
\hline \multicolumn{7}{|l|}{1600} \\
\hline ULH & $0.2^{\mathrm{a}}(0.1)$ & $5.4^{\mathrm{b}}(1.2)$ & $5.2^{\mathrm{b}}(1.3)$ & $0.3^{\mathrm{a}}(0.2)$ & $2.8^{\mathrm{a}}(0.8)$ & $0.2(0.0)$ \\
\hline UNN & $2.1^{\mathrm{b}}(0.9)$ & $5.4^{\mathrm{b}}(1.6)$ & $2.5^{\mathrm{a}}(0.6)$ & $3.2^{\mathrm{b}}(1.1)$ & $4.2^{\mathrm{a}}(1.3)$ & $0.5(0.0)$ \\
\hline WLH & $4.5^{\mathrm{c}}(1.4)$ & $8.6^{\mathrm{a}}(2.3)$ & $14.6^{\mathrm{c}}(3.5)$ & $10.2^{\mathrm{c}}(2.7)$ & $7.9^{\mathrm{b}}(2.4)$ & $0.1(0.0)$ \\
\hline WNN & $4.9^{\mathrm{c}}(1.5)$ & $4.4^{\mathrm{b}}(1.5)$ & $9.9^{\mathrm{c}}(2.6)$ & $13.7^{\mathrm{c}}(3.9)$ & $7.8^{\mathrm{b}}(2.1)$ & $0.0(0.0)$ \\
\hline
\end{tabular}

Notes: Values are means ( $\pm 1 \mathrm{SE})$ of a minimum of four plants. Within a column, means for a given date-and-time combination followed by the same letter were not significantly different at $P \leq 0.05$; there were no significant differences among means at any time of day on 6 August. ANOVA indicated treatment $\times$ time-of-day interactions were significant $(P \leq 0.05)$ at every date; treatment main effects were significant on all but the August date.

moisture levels (Fig. 2) were comparable. However, as water in the soil above $90 \mathrm{~cm}$ began to decline through June and July in the unwatered treatments, differences in physiological parameters became significant. Seedlings with supplemental water typically maintained higher levels of $A_{\mathrm{n}}$ (Table 3 ) and higher $\Psi$ (Table 4), relative to those not receiving supplemental water. Within a watering treatment, density and defoliation of herbaceous vegetation had virtually no influence on $A_{\mathrm{n}}$ or $\Psi$. By 6 August seedlings on both watered and unwatered plots had begun to shed leaves, even though soil moisture in the watered treatments remained quite high compared to the unwatered plots (Fig. 2). By 20 August, seedlings on both watered and unwatered plots had shed all leaves. $\Psi$ did not differ among treatments until July (Table 4). Predawn $\Psi$ was similar among seedlings regardless of treatment, except on 2 July and 16 July, when soil moisture was at the lowest level in unwatered plots.

Seedling height near the end of the first growing season was statistically comparable between treatments (pooled mean $\pm \mathrm{SE}$ for 1984 cohort $=3.6 \pm 0.3 \mathrm{~cm}$; 1985 cohort $=3.9 \pm 0.4 \mathrm{~cm})$. Aboveground biomass of the 1984 P. glandulosa cohort increased $38 \%$ between May and August 1985 (Table 5). However, height, leaf area, and aboveground biomass of these seedlings were not significantly different among treatments.

\section{DISCUSSION}

The intensity of grass-woody plant interactions should be mediated by resource availability (Scholes and Archer 1997). However, our field experiments indicated that reductions in grass biomass, achieved by defoliation and density reduction, had minimal influence on $P$. glandulosa emergence, aboveground growth, or survival. In addition, high rates of emergence on unwatered plots occurred even during months and years of substantially below-normal rainfall. Results therefore suggest that emergence and establishment of $P$. glandulosa can potentially occur in most years on this site, regardless of resource availability and livestock grazing pressure on grasses. This experimental evidence is consistent with results of $P$. glandulosa establishment trials in more mesic areas of central Texas, where we observed high rates of emergence $(43-60 \%)$ and survival $(74-97 \%)$ in experimental treatments spanning a similar range of aboveground biomass levels (Brown and Archer 1989).

\section{Seedling establishment was not episodic}

Discussions of vegetation change in drylands often emphasize event-driven or episodic processes (see Watson et al. 1996). The coefficient of variation of precipitation in the subtropical savannas of southern Texas $(35 \%)$ is among the highest reported for semiarid regions of the world (Le Houerou and Norwine 1988). Although mean annual rainfall at our study site is 760 $\mathrm{mm}$, tropical depressions and hurricanes in the Gulf of Mexico have generated annual rainfalls as high as 3300 mm. State Climatologist records for Alice, Texas, indicate there have been five years since 1912 when annual rainfall has exceeded $2600 \mathrm{~mm}(1919,1935,1941$, $1942,1971)$. We therefore hypothesized that establish- 
TABle 4. Xylem water potential (MPa) of $P$. glandulosa seedlings on six dates in 1985. Seedlings occurred on plots varying in their watering regime, herbaceous plant density, and level of defoliation (abbreviations as in Table 1).

\begin{tabular}{|c|c|c|c|c|c|}
\hline \multirow{2}{*}{$\begin{array}{l}\text { Time of day } \\
\text { and treatment }\end{array}$} & \multicolumn{5}{|c|}{ Date (1985) } \\
\hline & 3 May & 22 May & 2 July & 16 July & 6 August \\
\hline \multicolumn{6}{|l|}{0600} \\
\hline $\begin{array}{l}\text { ULH } \\
\text { UNN } \\
\text { WLH } \\
\text { WNN }\end{array}$ & $\begin{array}{l}-0.5(0.1) \\
-0.5(0.1) \\
-0.5(0.0) \\
-0.5(0.1)\end{array}$ & $\begin{array}{l}-0.5(0.1) \\
-0.5(0.1) \\
-0.5(0.1) \\
-0.5(0.0)\end{array}$ & $\begin{array}{l}-1.3^{\mathrm{a}}(0.2) \\
-1.3^{\mathrm{a}}(0.3) \\
-0.3^{\mathrm{b}}(0.0) \\
-0.3^{\mathrm{b}}(0.1)\end{array}$ & $\begin{array}{l}-1.8^{\mathrm{a}}(0.4) \\
-1.4^{\mathrm{a}}(0.2) \\
-0.3^{\mathrm{b}}(0.1) \\
-0.2^{\mathrm{b}}(0.0)\end{array}$ & $\begin{array}{l}-0.3^{\mathrm{a}}(0.0) \\
-0.3^{\mathrm{a}}(0.1) \\
-0.3^{\mathrm{a}}(0.1) \\
-0.3^{\mathrm{a}}(0.0)\end{array}$ \\
\hline \multicolumn{6}{|l|}{0900} \\
\hline $\begin{array}{l}\text { ULH } \\
\text { UNN } \\
\text { WLH } \\
\text { WNN }\end{array}$ & $\begin{array}{l}-1.8(0.2) \\
-1.7(0.3) \\
-1.6(0.3) \\
-1.5(0.2)\end{array}$ & $\begin{array}{l}-1.3(0.2) \\
-1.4(0.3) \\
-1.2(0.2) \\
-1.3(0.1)\end{array}$ & $\begin{array}{l}-4.0^{\mathrm{a}}(0.5) \\
-4.5^{\mathrm{a}}(0.4) \\
-1.4^{\mathrm{b}}(0.2) \\
-1.4^{\mathrm{b}}(0.1)\end{array}$ & $\begin{array}{l}-5.0^{\mathrm{a}}(0.6) \\
-4.1^{\mathrm{a}}(0.5) \\
-1.8^{\mathrm{b}}(0.4) \\
-1.7^{\mathrm{b}}(0.3)\end{array}$ & $\begin{array}{l}-1.0^{\mathrm{a}}(0.2) \\
-2.1^{\mathrm{b}}(0.3) \\
-1.3^{\mathrm{a}}(0.3) \\
-1.2^{\mathrm{a}}(0.2)\end{array}$ \\
\hline \multicolumn{6}{|l|}{1200} \\
\hline $\begin{array}{l}\text { ULH } \\
\text { UNN } \\
\text { WLH } \\
\text { WNN }\end{array}$ & $\begin{array}{l}-2.3(0.3) \\
-2.4(0.4) \\
-1.9(0.4) \\
-1.8(0.3)\end{array}$ & $\begin{array}{l}-1.8(0.3) \\
-1.9(0.4) \\
-2.1(0.4) \\
-1.9(0.3)\end{array}$ & $\begin{array}{l}-4.3^{\mathrm{a}}(0.4) \\
-4.6^{\mathrm{a}}(0.5) \\
-2.8^{\mathrm{b}}(0.3) \\
-2.3^{\mathrm{b}}(0.4)\end{array}$ & $\begin{array}{l}-4.9^{\mathrm{a}}(0.5) \\
-4.1^{\mathrm{a}}(0.5) \\
-2.7^{\mathrm{b}}(0.4) \\
-2.3^{\mathrm{b}}(0.3)\end{array}$ & $\begin{array}{l}-1.6^{\mathrm{a}}(0.4) \\
-2.6^{\mathrm{b}}(0.4) \\
-1.5^{\mathrm{a}}(0.3) \\
-1.6^{\mathrm{a}}(0.3)\end{array}$ \\
\hline \multicolumn{6}{|l|}{1600} \\
\hline $\begin{array}{l}\text { ULH } \\
\text { UNN } \\
\text { WLH } \\
\text { WNN }\end{array}$ & $\begin{array}{l}-2.1(0.3) \\
-2.0(0.3) \\
-1.8(0.2) \\
-1.7(0.4)\end{array}$ & $\begin{array}{l}-1.6(0.3) \\
-1.6(0.4) \\
-2.0(0.4) \\
-1.9(0.3)\end{array}$ & $\begin{array}{l}-4.2^{\mathrm{a}}(0.4) \\
-4.3^{\mathrm{a}}(0.3) \\
-2.4^{\mathrm{b}}(0.3) \\
-2.4^{\mathrm{b}}(0.1)\end{array}$ & $\begin{array}{l}-4.7^{\mathrm{a}}(0.4) \\
-4.1^{\mathrm{a}}(0.5) \\
-2.5^{\mathrm{b}}(0.3) \\
-2.4^{\mathrm{b}}(0.2)\end{array}$ & $\begin{array}{l}-2.2^{\mathrm{a}}(0.5) \\
-2.9^{\mathrm{a}}(0.7) \\
-1.4^{\mathrm{b}}(0.5) \\
-1.3^{\mathrm{b}}(0.3)\end{array}$ \\
\hline
\end{tabular}

Notes: Values are means ( $\pm 1 \mathrm{SE})$ of a minimum of three plants. Within a column, means for a given date-and-time combination followed by the same letter are not significantly different $(P \leq 0.05$; there were no significant differences among means at any time of day on 3 May or 22 May). ANOVA indicated significant treatment $\times$ time-of-day interactions on each date; treatment main effects were significant in July and August.

ment of woody plants such as $P$. glandulosa might be confined to such years. However, in our study, rates of $P$. glandulosa emergence on unwatered (natural rainfall only) plots were high (38-48\%), even during months and years of substantially below-normal rainfall. This is, perhaps, not surprising, given that $P$. glandulosa is well-adapted to hot desert regions where mean annual rainfall is much lower than that in the central- and southern-Texas portion of its geographic range. In our study, increasing soil moisture enhanced recruitment by increasing seedling emergence rather than seedling survival. Supplemental watering increased emergence by $18 \%$, perhaps by ameliorating soil temperatures. The optimum temperature for $P$. glandulosa germination is $25-30^{\circ} \mathrm{C}$ (Haas et al. 1973) and soil temperatures in excess of $35^{\circ} \mathrm{C}$ reduce emergence by retarding imbibition (Scifres and Brock 1969). Temperatures at $5 \mathrm{~cm}$ on watered plots were $<32^{\circ} \mathrm{C}$, whereas temperatures on unwatered plots exceeded $38^{\circ} \mathrm{C}$ after sowing.

The size and age-class distribution of P. glandulosa on this site shows no indication of episodic establishment or mortality (Archer 1989, Boutton et al. 1998) and confirms our experimental assessment that $P$. glandulosa recruitment could have been relatively continuous over the last $100 \mathrm{yr}$ in this bioregion. This contrasts with observations from more arid systems, where establishment of Prosopis (Turner 1990; R. E. Miller and L. F. Huenneke, unpublished manuscript) and other woody plants (Harrington 1991, O'Connor 1995a, b, Wiegand et al. 1995) may occur rarely and during years with unusually high rainfall. Even so, "continuous" recruitment of shrubs in relatively arid systems may be more important than the dogma of "event-driven" or episodic recruitment would suggest (Watson et al. 1997). Management and modeling of grass and woody plant interactions in dryland systems should therefore be cognizant of the need to balance appropriately the effects of infrequent, unpredictable events, as measured at decadal time scales, and the effects of more continuous processes, as measured in time scales of years (Watson et al. 1996). Given the potentially differential effects of increases in atmospheric $\mathrm{CO}_{2}$ concentration (e.g., Polley et al. 1994, 1996) and changes in rainfall seasonality (Brown et al. 1997) on growth of woody plants and grasses, the reconstruction and extrapolation of woody plant seedling establishment dynamics must be made cautiously.

\section{Herbaceous plants had little effect on Prosopis recruitment}

$P$. glandulosa successfully emerged and established across a broad range $\left(185-453 \mathrm{~g} / \mathrm{m}^{2}\right)$ of aboveground herbaceous biomass levels achieved by clipping and by reducing plant density. The fact that $P$. glandulosa seedling gas exchange, water relations, height growth, and survival were minimally influenced by herbaceous manipulation may reflect the ability of $P$. glandulosa quickly to elongate tap roots and access soil moisture beyond the zone effectively exploited by grasses (Brown and Archer 1990). Although seedlings on wa- 
TABLE 5. Mean ( $\pm 1 \mathrm{SE}$ ) height $(\mathrm{cm})$, aboveground biomass $(\mathrm{mg})$, and leaf area $\left(\mathrm{cm}^{2}\right)$ of Prosopis seedlings emerging in July 1984.

\begin{tabular}{llccc}
\hline \hline Year & Month & $\begin{array}{c}\text { Height } \\
(\mathrm{cm})\end{array}$ & $\begin{array}{c}\text { Biomass } \\
(\mathrm{mg})\end{array}$ & $\begin{array}{c}\text { Leaf area } \\
\left(\mathrm{cm}^{2}\right)\end{array}$ \\
\hline 1984 & September & $3.6 \pm 0.3$ & $\ldots$ & $\ldots$ \\
1985 & May & $4.2 \pm 0.7$ & $90.8 \pm 5.7$ & $2.4 \pm 0.2$ \\
& August & $5.4 \pm 1.1$ & $125.5 \pm 7.8$ & $1.1 \pm 0.4$
\end{tabular}

Notes: There were no significant differences $(P>0.05)$ among density, defoliation, or watering treatments, so data were pooled. Seedlings were not destructively harvested in 1984 . Height values represent all seedlings $(N>400)$; biomass and leaf area values taken from plants harvested for gas exchange and water relations data $(N=50)$.

tered plots had higher $A_{\mathrm{n}}$ and $\Psi$, this did not translate into increased aboveground height, leaf area, or biomass. This may indicate that allocation to root growth is a priority in $P$. glandulosa seedlings over a wide range of resource availabilities. Competition between grasses and $P$. glandulosa seedlings is primarily belowground (van Auken and Bush 1997), so preferential allocation to root development would enable resource partitioning and coexistence of $P$. glandulosa seedlings with grasses early in their life cycle, minimize competitive exclusion, and give seedlings access to deeper, more stable supplies of soil moisture. Similar mechanisms appear to enable successful recruitment of Pinus radiata (Sands and Sandian-Nambier 1984) and of oaks (Quercus spp.) in semiarid savanna (McPherson 1993, Weltzin and McPherson 1997) and tallgrass prairie (Bragg et al. 1993). Conversely, the inability of woody plant seedlings to extend roots below the depth of grass roots before soil drying can place significant constraints on establishment (Gordon et al. 1989, Williams and Hobbs 1989).

The effects of herbaceous vegetation on woody plant recruitment are variable, and multiple mechanisms can operate in complex ways to influence emergence and establishment (Burton and Bazzaz 1991, De Steven $1991 a, b)$. While grasses may reduce emergence, growth, and survival of woody seedlings (Gordon et al. 1989, Martinez and Fuentes 1993, McPherson 1993), including P. glandulosa (Bush and van Auken 1989, 1995, van Auken and Bush 1989, 1997, Polley et al. 1994), the competitive reduction may not be large, and high mortality or complete exclusion may seldom occur. For example, Schmidt and Stubbendieck (1993) found that although survival of evergreen tree (Juniperus virginiana) seedlings was highest in grazed pastures $(57 \%)$, survival of seedlings in pastures that had not been grazed for $>50$ yr was still $40 \%$. In South African grasslands, Acacia karroo seedings were capable of establishing and surviving within dense grass swards (O'Connor 1995a). In Argentinean grasslands, survival and growth of $P$. caldenia seedlings on sites protected from grazing exceeded that of seedlings on sites subjected to long-term heavy grazing (Distel et al. 1996). In the Post Oak Savanna of central Texas, Prosopis seedling emergence was low (6-8\%), but not nil, on plots protected from grazing for $40 \mathrm{yr}$ (Brown and Archer 1989), and only moderate defoliation of grasses was required to produce an eight-fold increase in emergence. Subsequent survival of all seedlings exceeded $80 \%$, implying that thresholds for biotic regulation of Prosopis emergence and establishment (Archer 1989, 1995a) are exceeded at low levels of herbaceous disturbance.

Traditional rangeland management practices are predicated on the notion that "proper grazing" can minimize woody plant invasion problems. The implicit assumption is that adjusting stocking rates to maintain grass composition, cover, and biomass will minimize tree and shrub encroachment. The results from numerous grass-shrub seedling competition container experiments cited earlier substantiate this assumption. However, data from this field competition experiment and others (e.g., Brown and Archer 1989, Goerner 1993, Schmidt and Stubbendieck 1993, O'Connor 1995a, Weltzin et al. 1997, Brown and Carter 1998) suggest grazing management strategies to mitigate invasion by unpalatable woody plants should not focus on grass-shrub seedling interference, but instead on minimizing seed dispersal (in the case of leguminous shrubs where livestock may be primary vectors) and on maintaining an effective fire regime.

In summary, the results of our field experiments concur with field observations that indicate woody plant encroachment into grasslands can be high, regardless of grazing pressure or herbaceous composition and biomass (Brown 1950, Paulsen 1950, Humphrey and Mehrhoff 1958, Smith and Schmutz 1975, Bragg and Hulbert 1976, Meyer and Bovey 1982, Hennessy et al. 1983, Towne and Owensby 1984, Smeins and Merrill 1988). Grass utilization by grazing animals may not be a prerequisite for woody plant encroachment, except as described below.

\section{Why has Prosopis abundance increased in recent history?}

Given the relative ease of establishment and the high survival rates of woody plants such as $P$. glandulosa in grassland and savanna systems, why has their abundance increased only recently? The spread of $P$. glandulosa into Holocene grasslands may have been limited by a lack of effective dispersal agents, a constraint overcome by the introduction of horses, cattle, and sheep into North America (Brown and Archer 1987). Alternatively, $P$. glandulosa, which is capable of vegetative regeneration within 2 wk of germination (Scifres and Hahn 1971), tolerant of repeated top removal during its first growing season (Weltzin et al. 1998), and tolerant of hot fires by its second and third year of growth (Wright et al. 1976), may have always been present in southwestern grassland landscapes as a "seedling bank," but its dominance suppressed by pe- 
riodic fire. Reductions in fire frequency and intensity resulting from reductions in fine fuel mass and continuity associated with heavy, continuous livestock grazing (Baisan and Swetnam 1990, Savage and Swetnam 1990, Covington and Moore 1994) would then have allowed established, but suppressed, woody plants such as $P$. glandulosa to increase in stature, express dominance over the surrounding herbaceous vegetation, and attain seed-bearing size. In the absence of fire, $P$. glandulosa's expansion into mesic and semiarid grassland with a history of livestock grazing may be regulated more by rates and patterns of seed dispersal and the presence or absence of "seedling predators" (Weltzin et al. 1997) than by abiotic conditions or herbaceous competition.

\section{ACKNOWLEDGMENTS}

We thank Jerry Stuth for the use of equipment and travel funds. G. Harrington and J. Scanlan reviewed earlier drafts of the manuscript and made helpful comments. The submitted manuscript benefitted from the constructive comments provided by A. Black and two anonymous reviewers.

\section{Literature Cited}

Archer, S. 1989. Have Southern Texas savannas been converted to woodlands in recent history? American Naturalist 134:545-561.

. 1994. Woody plant encroachment into southwestern grasslands and savannas: rates, patterns and proximate causes. Pages 13-68 in M. Vavra, W. Laycock, and R. Pieper, editors. Ecological implications of livestock herbivory in the West. Society for Range Management, Denver, Colorado, USA.

1995a. Herbivore mediation of grass-woody plant interactions. Tropical Grasslands 29:218-235.

- 1995b. Tree-grass dynamics in a Prosopis-thornscrub savanna parkland: reconstructing the past and predicting the future. Ecoscience 2:83-99.

Archer, S., D. S. Schimel, and E. A. Holland. 1995. Mechanisms of shrubland expansion: land use, climate, or $\mathrm{CO}_{2}$ ? Climatic Change 29:91-99.

Baisan, C. H., and T. W. Swetnam. 1990. Fire history on a desert mountain range: Rincon Mountain Wilderness, Arizona, USA. Canadian Journal of Forest Research 20:15591569.

Ben-Sharer, R. 1992. The effects of bush clearance on African ungulates in a semiarid nature reserve. Ecological Applications 2:95-101.

Boutton, T. W., S. Archer, A. J. Midwood, S. F. Zitzer, and R. Bohl. 1998. $\delta^{13} \mathrm{C}$ values of soil organic carbon and their use in documenting vegetation change in a subtropical savanna ecosystem. Geoderma 82:5-41.

Bragg, T. B., and L. C. Hulbert. 1976. Woody plant invasion of unburned Kansas bluestem prairie. Journal of Range Management 29:19-23.

Bragg, W. K., A. K. Knapp, and J. M. Briggs. 1993. Comparative water relations of seedling and adult Quercus species during gallery forest expansion in tallgrass prairie. Forest Ecology and Management 56:29-41.

Brown, A. L. 1950. Shrub invasions of southern Arizona desert grasslands. Journal of Range Management 3:172177.

Brown, J. H., T. J. Valone, and C. G. Curtin. 1997. Reorganization of an arid ecosystem in response to recent climate change. Proceedings National Academy of Science 94:9729-9733.

Brown, J. R., and S. Archer. 1987. Woody plant seed dis- persal and gap formation in a North American subtropical savanna woodland: the role of domestic herbivores. Vegetatio 73:73-80.

Brown, J. R., and S. Archer. 1989. Woody plant invasion of grasslands: establishment of honey mesquite (Prosopis glandulosa var. glandulosa) on sites differing in herbaceous biomass and grazing history. Oecologia 80:19-26.

Brown, J. R., and S. Archer. 1990. Water relations of a perennial grass and seedling vs. adult woody plants in a subtropical savanna, Texas. Oikos 57:366-374.

Brown, J. R., and J. Carter. 1998. Spatial and temporal patterns of exotic shrub invasion in an Australian tropical grassland. Landscape Ecology 13:93-103.

Burton, P. J., and F. A. Bazzaz. 1991. Tree seedling emergence on interactive temperature and moisture gradients and in patches of old-field vegetation. American Journal of Botany 78:131-149.

Bush, J. K., and O. W. van Auken. 1989. Soil resource levels and competition between a woody and herbaceous species. Bulletin Torrey Botanical Club 116:22-30.

Bush, J. K., and O. W. van Auken. 1995. Woody plant growth related to planting time and clipping of $\mathrm{a}_{4}$ grass. Ecology 76:1603-1609.

Carter, J. O. 1994. Acacia nilotica: a tree legume out of control. Pages 338-351 in Gutteridge, R. C., and Shelton, H. M., editors. Forage tree legumes in tropical agriculture. CAB International, Wallingford, Oxford, UK.

Carter, M. G. 1964. Effects of drouth on mesquite. Journal of Range Management 17:275-276.

Correll, D. S., and M. C. Johnston. 1979. Manual of the vascular plants of Texas. University of Texas at Dallas, Richardson, Texas, USA.

Covington, W. W., and M. M. Moore. 1994. Southwestern ponderosa forest structure: changes since Euro-American settlement. Journal of Forestry 92:39-47.

Davis, R. B., and R. L. Spicer. 1965. Status of the practice of brush control in the Rio Grande Plain. Texas Parks and Wildlife Department, Austin, Texas, USA.

De Steven, D. 1991a. Experiments on mechanisms of tree establishment in old-field succession: seedling emergence. Ecology 72:1066-1075.

- $1991 b$. Experiments on mechanisms of tree establishment in old-field succession: seeding survival and growth. Ecology 72:1076-1088.

Distel, R. A., D. V. Peláez, R. M. Boo, M. D. Mayor, and O. R. Elía. 1996. Growth of Prosopis caldenia seedlings in the field as related to grazing history of the site and in a greenhouse as related to different levels of competition from Stipa tenuis. Journal of Arid Environments 32:251257.

Fisher, C. E. 1950. The mesquite problem in the southwest. Journal of Range Management 3:60-70.

Goerner, C. A. 1993. Aboveground interference, litter and light quality influence on Prosopis glandulosa var. glandulosa establishment in grasslands. Thesis, Texas A\&M University, College Station, Texas, USA.

Goldberg, D. A., and P. A. Werner. 1983. Effects of size of opening in vegetation and litter cover on seedling establishment of goldenrod. Oecologia 60:149-155.

Gordon, D. R., J. M. Welker, J. W. Menke, and K. J. Rice. 1989. Competition for soil water between annual plants and blue oak (Quercus douglasii) seedlings. Oecologia 79: 533-541.

Grover, H. D., and H. B. Musick. 1990. Shrubland encroachment in southern New Mexico, USA: an analysis of desertification processes in the American southwest. Climatic Change 17:305-330.

Haas, R. H., R. E. Meyer, C. J. Scifres, and J. H. Brock. 1973. Growth and development of mesquite. Pages 10-19 in C. J. Scifres, R. W. Bovey, C. E. Fisher, G. O. Hoffman, 
and R. D. Lewis, editors. Mesquite: growth and development, management, economics, control, uses. Texas Agricultural Experiment Station, College Station, Texas, USA.

Harper, J. L. 1977. The population biology of plants. Academic Press, New York, New York, USA.

Harrington, G. N. 1991. EFfects of soil moisture on shrub seedling survival in a semi-arid grassland. Ecology 72: $1138-1149$.

Heitschmidt, R. K., and J. W. Stuth, editors. 1991. Grazing management: an ecological perspective. Timberline Press, Portland, Oregon, USA.

Hennessy, J. T., R. P. Gibbens, and J. M. Tromble. 1983. Vegetation changes from 1935 to 1980 in mesquite dune lands and former grasslands of southern New Mexico. Journal of Range Management 36:370-374.

Humphrey, R. R., and L. A. Mehrhoff. 1958. Vegetation change on a southern Arizona grassland range. Ecology 39: 720-726.

Keppel, G. 1982. Design and analysis: a researcher's handbook. Prentice-Hall, Englewood Cliffs, New Jersey, USA

Le Houerou, H. N., and J. Norwine. 1988. The ecoclimatology of South Texas. Pages 417-444 in E. E. Whitehead, C. F. Hutchinson, B. N. Timmesman, and R. G. Varady, editors. Arid lands: today and tomorrow Westview Press, Boulder, Colorado, USA.

Madany, M. H., and N. E. West. 1983. Livestock grazingfire regime interactions within montane forests of Zion National Park, Utah. Ecology 64:661-667.

Maguire, D. A., and R. T. T. Forman. 1983. Herb cover effects on tree seedling patterns in a mature hemlockhardwood forest. Ecology 64:1367-1380.

Martinez, E., and E. Fuentes. 1993. Can we extrapolate the California model of grassland-shrubland ecotone? Ecological Applications 3:417-423.

McEvoy, P. B. 1984. Dormancy and dispersal in dimorphic achenes of tansey ragwort Scencio jocoboea L. (Compositae). Oecologia 61:160-168.

McPherson, G. R. 1993. Effects of herbivory and herb interference on oak establishment in a semi-arid temperate savanna. Journal of Vegetation Science 4:687-692.

-1997. Ecology and management of North American savannas. University of Arizona Press, Tucson, Arizona, USA.

McPherson, G. R., and H. A. Wright. 1990. Effects of cattle grazing and Juniperus pinchotii canopy cover on herb cover and production in western Texas. American Midland Naturalist 123:144-151.

Meyer, R. E., and R. W. Bovey. 1982. Establishment of honey mesquite and huisache on a native pasture. Journal of Range Management 35:548-550.

Neilson, R. P., and L. H. Wullstein. 1985. Comparative drought physiology and biogeography of Quercus gambeli and Quercus turbinella. American Midland Naturalist 114: 259-271.

O'Connor, T. G. 1993. The influence of rainfall and grazing on the demography of some African savanna grasses: a matrix modelling approach. Journal of Applied Ecology 30 119-132.

. 1995a. Acacia karoo invasion of grassland: environmental and biotic effects influencing seedling emergence and establishment. Oecologia 103:214-223.

- 1995b. Transformation of a savanna grassland by drought and grazing. African Journal of Range and Forage Science 12:53-60

Paulsen, N. A. 1950. Mortality of velvet mesquite seedlings. Journal of Range Management 3:281-286.

Polley, H. W., H. B. Johnson, and H. S. Mayeux. 1994. Increasing $\mathrm{CO}_{2}$ : comparative responses of the $\mathrm{C}_{4}$ grass $\mathrm{Schi}$ zachyriuim and grassland invader Prosopis. Ecology 75: 976-988
Polley, H. W., H. B. Johnson, H. S. Mayeux, and C. R. Tischler. 1996. Are some of the recent changes in grassland communities a response to rising $\mathrm{CO}_{2}$ concentrations? Pages 177-195 in C. Korner and F. A. Bazzaz, editors. Carbon dioxide, populations and communities. Academic Press, San Diego, California, USA.

Sands, R., and Sandian-Nambiar, E. K. 1984. Water relations of Pinus radiata in competition with weeds. Canadian Journal of Forest Research 14:233-237.

Savage, M., and T. W. Swetnam. 1990. Early 19th-century fire decline following sheep pasturing in a Navajo ponderosa pine forest. Ecology 71:2374-2378.

Schlesinger, W. H., J. F. Reynolds, G. L. Cunningham, L. F. Huenneke, W. M. Jarrell, R. A. Virginia, and W. G. Whitford. 1990. Biological feedbacks in global desertification. Science 24:1043-1048.

Schmidt, T. L., and J. Stubbendieck. 1993. Factors influencing eastern redcedar seedling survival on rangeland. Journal of Range Management 46:448-451.

Scholander, P. F., H. T. Hammel, E. D. Bradstreet, and E. A. Hemmingsen. 1965. Sap pressure in vascular plants. Science 148:339-345.

Scholes, R. J., and S. Archer. 1997. Tree-grass interactions in savannas. Annual Review of Ecology \& Systematics 28: 517-544.

Schultz, A. M., J. L. Launchbaugh, and H. H. Biswell. 1955. Relationship between grass density and brush seedling survival. Ecology 36:226-238.

Scifres, C. J. 1980. Brush management: principles and practices for Texas and the Southwest. Texas A\&M University Press, College Station, Texas, USA.

Scifres, C. J., and J. H. Brock. 1969. Moisture-temperature interrelations in germination and early seedling development of mesquite. Journal of Range Management 22:334337.

Scifres, C. J., and R. R. Hahn. 1971. Response of honey mesquite seedlings to top removal. Journal of Range Management 24:396-398.

Scifres, C. J., W. T. Hamilton, J. M. Inglis, and J. R. Conner. 1983. Development of integrated brush management systems (IBMS): decision-making processes. Pages 97-104 in K. W. McDaniel, editor. Proceedings Brush Management Symposium, Texas Tech Press, Lubbock, Texas, USA.

Simpson, B. B., editor. 1977. Mesquite: its biology in two desert scrub ecosystems. Halstead Press, New York, New York, USA.

Smeins, F. E., and L. B. Merrill. 1988. Long-term change in semi-arid grassland. Pages 101-114 in B. B. Amos and F. R. Gehlback, editors. Edwards Plateau vegetation. Baylor University Press, Waco, Texas, USA.

Smith, D. A., and E. M. Schmutz. 1975. Vegetative changes on protected versus grazed desert grassland range in Arizona. Journal of Range Management 28:453-457.

Snedecor, G. W., and W. G. Cochran. 1980. Statistical methods. Iowa State University Press, Des Moines, Iowa, USA.

Towne, G., and C. Owensby. 1984. Long-term effects of annual burning at different dates in ungrazed Kansas tallgrass prairie. Journal of Range Management 37:392-396.

Turner, R. M. 1990. Long-term vegetation change at a fully protected Sonoran Desert site. Ecology 71:464-477.

USDA. 1979. Soil survey of Jim Wells County, Texas. United States Department of Agriculture-Soil Conservation Service, Temple, Texas, USA.

van Auken, O. W., and J. K. Bush. 1987. Influence of plant density on the growth of Prosopis glandulosa var. glandulosa and Buchloe dactyloides. Bulletin of the Torrey Botanical Club 114:393-401.

van Auken, O. W., and J. K. Bush. 1988. Competition between Schizachyrium scoparium and Prosopis glandulosa. American Journal of Botany 75:782-789. 
van Auken, O. W., and J. K. Bush. 1989. Prosopis glandulosa growth: influence of nutrients and simulated grazing of Bouteloua curtipendula. Ecology 70:512-516.

van Auken, O. W., and J. K. Bush. 1997. Growth of Prosopis glandulosa in response to changes in aboveground and belowground interference. Ecology 78:1222-1229.

van Bavel, C. M. H. 1958. Measurement of soil moisture content by the neutron scattering method. USDA Research Service Bulletin 4124, Beltsville, Maryland, USA.

Watson, I. W., D. G. Burnside, and A. M. Holm. 1996. Eventdriven or continuous: which is the better model for managers? The Rangeland Journal 18:351-369.

Watson, I. W., M. Westoby, and A. M. Holm. 1997. Continuous and episodic components of demographic change in arid zone shrubs: models of two Eremophila species from western Australia compared with published data on other species. Journal of Ecology 85:833-846.

Weltzin, J. F., S. Archer, and R. K. Heitschmidt. 1997. Small mammal regulation of vegetation structure in a temperate savanna. Ecology 78:751-763.

Weltzin, J., S. Archer, and R. Heitschmidt. 1998. Defoliation and woody plant (Prosopis glandulosa) seedling establishment: potential vs. realized herbivory tolerance. Plant Ecology, in press.

Weltzin, J. F., and G. R. McPherson. 1997. Spatial and temporal soil moisture resource partitioning by trees and grasses in a temperate savanna, Arizona, USA. Oecologia 112: 156-164.

Wiegand, T., S. J. Milton, and C. Wissel. 1995. A simulation model for a shrub ecosystem in the semiarid Karoo, South Africa. Ecology 76:2205-2221.

Williams, K., and R. J. Hobbs. 1989. Control of shrub establishment by springtime soil water availability in an annual grassland. Oecologia 81:62-66.

Wright, H. A., S. C. Bunting, and L. F. Neuenschwander. 1976. Effect of fire on honey mesquite. Journal of Range Management 29:467-471. 